Animal Health Research Institute, Damanhour Branch.

\title{
STUDY ON THE MICROBIOLOGICAL CONTENT OF LOCAL MANUFACTURED POULTRY MEAT PRODUCTS IN EL-BOHIRA GOVERNORATE
}

\author{
(With 3 Tables)
}

By

\section{A.A. BKHEET; M.SH. REZK and M.M. MOUSA* \\ * Faculty of Vet. Med. Alex. Univ. \\ (Received at 18/12/2006)}

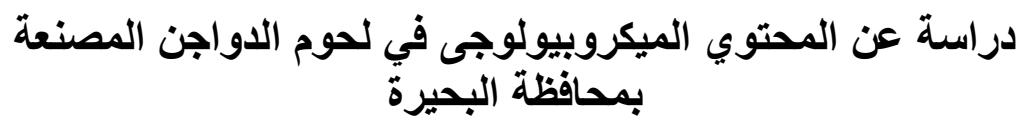

أحد أبو المجب بخيث ، محمد شوقى زنق ، محد محد موسى

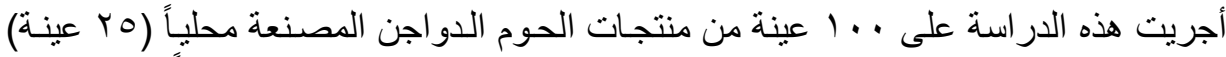

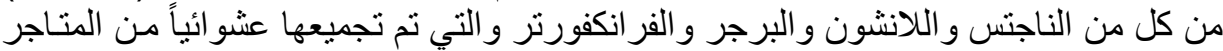

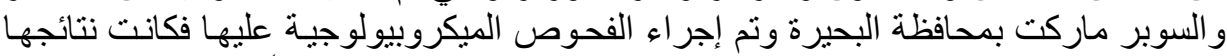

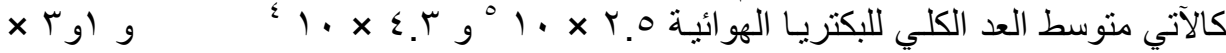

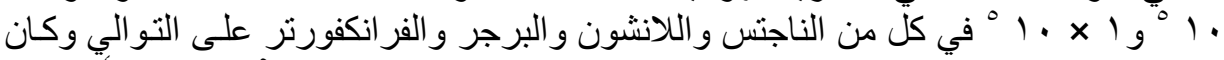

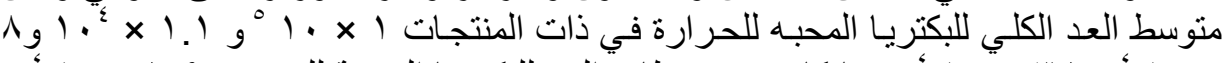

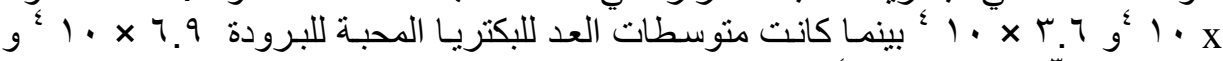
r.

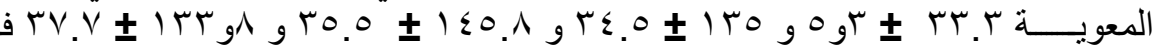

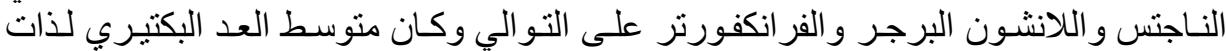

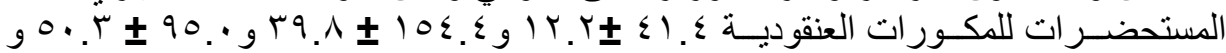

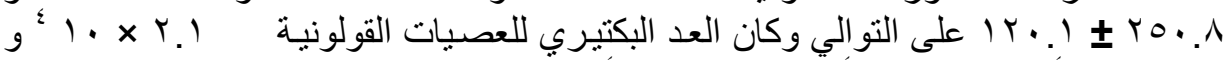

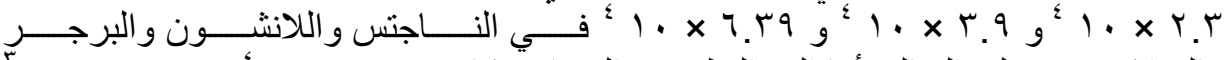

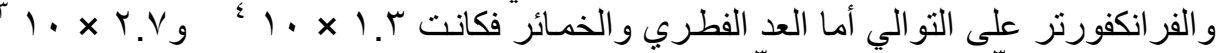

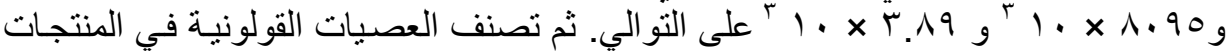

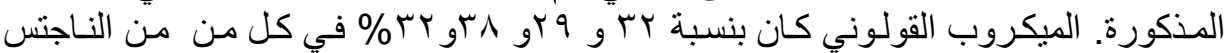

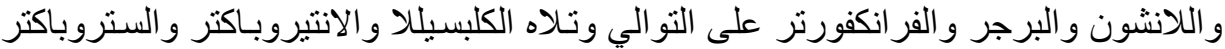

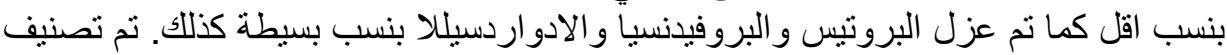

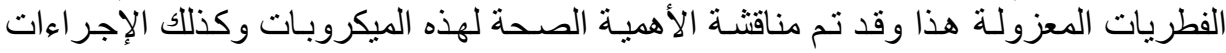

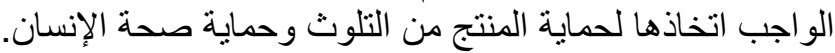


A total of 100 random samples of poultry meat products (25 each of chicken burger, luncheon, nuggets and frankfurter) were collected from supermarkets and groceries of Al-Bohira governorate. The samples were examined microbiologically to estimate their sanitary condition. The mean mesophilic counts were $2.6 \times 10^{5}, 4.3 \times 10^{4}, 3.1 \times 10^{5}$ and $1 \times 10^{5}$ in nuggets, luncheon, burger and frankfurter respectively. The mean thermophilic counts were $1 \times 10^{5}, 1.1 \times 10^{4}, 8 \times 10^{4}$ and $3.6 \times 10^{4}$ respectively. The mean psychrotphic counts were $6.9 \times 10^{4}, 6.2 \times 10^{3}$, $3.9 \times 10^{4}$ and $1.1 \times 10^{5}$ respectively and that of enterococci counts were $33.3 \pm 5.3,135 \pm 34.5,145.8 \pm 35.5$ and $133.8 \pm 37.8$ in burger, luncheon, nuggets and frankfurter respectively. The mean staphylococci counts were $41.4 \pm 12.2,154.4 \pm 39.9,95 \pm 50.3$ and $250 \pm 120.1$. The mean coliform counts were $2.1 \times 10^{4}, 2.3 \times 10^{4}, 3.9 \times 10^{4}$ and $6.4 \times 10^{3}$ and that of mould and yeast counts were $1.3 \times 10^{4}, 2.7 \times 10^{3}, 8.9 \times 10^{3}$ and $3.9 \times 10^{3}$ respectively. The public health hazard of the isolated and identified organisms such as staphylococci, enterococci, E.coli, Citrobacter, Proteus, and mould and yeast, as well as suggestions to increase the shelflife of the products and protect consumers were discussed.

Key words: Poultry meat products, staphylococci, enterococci, coliforms, fungi

\section{INTRODUCTION}

Poultry meat products comprise a substantial of the human diet. Clearly the continual growth and prosperity of the poultry industry will depend. on its ability to supply the consumer safe products. However, the presence of pathogenic and/or spoilage micro-organisms in poultry products remain a significant concern In addition the presence of microbial hazard such as pathogenic bacteria as a microbial toxin, in ready to eat poultry products may be found. Poultry meat and their products often get contamination from different sources starting from defeathering, evisceration and the subsequent processing plant (Roberts, 1988; Todd 1989; Levin, et al., 2001 and Houf, et al., 2002)

Coliform have an epidemiological interest and importance, as some of which were pathogenic and may cause serious intestinal infection and food poisoning. Coliform count was greatly considered to be suitable indicator for fecal contamination (Mercuri and Cox, 1979, Mousa et al., 2001).

Enterococci group has an epedemiologisal interest and importance as some are pathogenic and may cause serious ent astinal 
affections and food poisoning (ICMSF, 1978, Mossel, et al., 1978). Enterococci constitute a public health hazard as pathogenic, toxigenic in extraintestinal disease as endocarditis ( $\mathrm{El}$ - Khateib, et al., 1989).

Streptococci of lancefind 's grooup D caused systemis disease in men like febrile gastrointeritis as well as their function as indicator organisms of fecal cont amination(Mossel, et al., 1978 )

Staph.aureus is important in relation to poultry meat hygiene because of its ability to produce enterotoxins which is one of the major cause of food borne illness (Jablonski and Bohach, 1997, Gracey, et al. 1999) Moreover Doyle and padhye (1989) estimated that, 24 million as more cases per year in Untied State affected by food borne diarrhoeal disease caused by Staph aureus food poisoning.

The funny climate in Egypt performs suitable environment for mould and yeast growth which performs importance in checking general sanitary condition and public health point of view by moulds and yeast and their mycotoxines released (Bullerman, 1979, Samaha, et al., 2003) The present study was carried to evaluate the microbiological aspect of some poultry products, frank forter, nuggets, burger and luncheon, to assess the sanitary measures and public health hazards.

\section{MATERIALS and METHODS}

A total of 100 random samples of poultry meat products (luncheon, nuggets, burger and frankfurter) 25 of each were collected from different supermarkets in Al-Bohira governorate. $10 \mathrm{gm}$ from each sample were taken and put in a sterile plastic bag in a stomacher lab blender, then $90 \mathrm{ml}$ of $0.1 \%$ sterile peptone water were added and the decimal dilutions up to $10^{-6}$ were prepared. The samples were subjected to two lines of examination:

A- Quantitative testing of total mesophilic, thermophilic and psychotropic bacterial counts where one $\mathrm{ml}$ from each dilution was transferred into plate count agar and the cultured plates (3 to each sample) were incubated at 37,45 , and $7^{\circ} \mathrm{C}$ respectively for $24-48 \mathrm{hr}$, plates with range of 30-300 colonies were counted.

$\mathrm{B}$ - Isolation and identification of enterococci by spreading one $\mathrm{ml}$ of previously prepared dilutions on kanamycin asculin media (Mossel et al., 1978) Incubate at $37^{\circ} \mathrm{C}$. Black colonies surrounded by black holes were counted. Further identifications were carried according to (Krieg and Holt 1984)

C- Isolation and identification of staphylococci (Baird Parker, 1964). From each prepared dilution. $0.1 \mathrm{ml}$ was inoculated into the surface of 
Baird parker agar plates and spread with sterile glass rod and incubated at $37^{\circ} \mathrm{C}$ for $24-48 \mathrm{hr}$, bright black colonies were counted as positive. Suspected Staphylococci colonies were picked up and kept for further biochemical identifications (Cruickshanke et al., 1975)

D- Total mould and yeast count: One $\mathrm{ml}$ from original dilutions was streaked onto Sabourauds dextrose agar and incubated at $25^{\circ} \mathrm{C}$, and examined daily for 5 days.

\section{RESULTS}

Table 1: Statistical analytical results of mean mesophilic, thermophilic, psychrophilic, enterococci, staphylococci, coliform and mould and yeast in the examined chicken meat products $(\mathrm{n}=25)$.

\begin{tabular}{|c|c|c|c|c|c|c|c|c|c|c|c|c|}
\hline & \multicolumn{3}{|c|}{ Nuggets } & \multicolumn{3}{|c|}{ Luncheon } & \multicolumn{3}{|c|}{ Burger } & \multicolumn{3}{|c|}{ Frank fort } \\
\hline Isolates & $\mathrm{N}$ & $\%$ & $X \pm S E$ & $\mathrm{~N}$ & $\%$ & $\mathrm{X} \pm \mathrm{SE}$ & $\mathrm{N}$ & $\%$ & $X \pm S E$ & $\mathrm{~N}$ & $\%$ & $\mathrm{X} \pm \mathrm{SE}$ \\
\hline Mesophilic & 25 & 100 & $2.6 \times 10^{5} \pm 8.9 \times 10^{4}$ & 25 & 100 & $4.3 \times 10^{4} \pm 5.72 \times 10^{3}$ & 25 & 100 & $3.1 \times 10^{5} \pm 7 . \times 10^{4}$ & 25 & 100 & $1 . \times 10^{5} \pm 32 \times 10^{4}$ \\
\hline Thermo & 25 & 100 & $1 \times 10^{5} \pm .3 .4 . \times 10^{4}$ & 25 & 100 & $1.1 \times 10^{4} \pm 2.7 \times 10^{3}$ & 23 & 92 & $8 . \times 10^{4} \pm 2.6 \times 10^{4}$ & 23 & 92 & $3.6 \times 10^{4} \pm 12 \times 10^{4}$ \\
\hline Psychro & 19 & 76 & $6.9 \times 10^{4} \pm 2.1 \times 10^{4}$ & 22 & & $6.2 \times 10^{3} \pm 9 . \times 10^{2}$ & 22 & 88 & $3.9 \times 10^{4} \pm 1.9 \times 10^{4}$ & 21 & 84 & $1.1 \times 10^{5} \pm 4.63 \times 10^{4}$ \\
\hline Entero.c & 9 & 36 & $33.3 \pm 5.3$ & 16 & 64 & $135 \pm 34.5$ & 12 & 48 & $145.8 \pm 35.5$ & 16 & 64 & $133.8 \pm 37.7$ \\
\hline Staph.c & 7 & 28 & $41.4 \pm 12.2$ & 9 & 36 & $154.4 \pm 39.9$ & 6 & 24 & $95 \pm 50.3$ & 3 & 12 & $25 \pm 120.1$ \\
\hline Coliform & 22 & 88 & $2.1 \times 10^{4} \pm 2.3 \times 10^{3}$ & 24 & 96 & $2.3 \times 10^{4} \pm 2.2 \times 10^{3}$ & 21 & 84 & $39 \times 10^{4} \pm 1 \times 10^{4}$ & 18 & 72 & $64 \times 10^{3} \pm 1 \times 10^{3}$ \\
\hline $\begin{array}{l}\text { Mould\& } \\
\text { yeast }\end{array}$ & 13 & 52 & $1.4 \times 10^{4} \pm 2.4 \times 10^{2}$ & 15 & 60 & $2.7 \times 10^{3} \pm 1.4 \times 10^{3}$ & 22 & 88 & $8.9 \times 10^{3} \pm 3.1 \times 10^{3}$ & 9 & 36 & $39 \times 10^{3} \pm 1 \times 10^{3}$ \\
\hline
\end{tabular}

$\mathbf{N}=$ Number of positive samples $\quad \mathbf{X}=$ Mean count $\quad \mathbf{S} \mathbf{E}+$ standard error of the mean.

Table 2: Incidence of identified Gram + ve cocci and mould and yeasts in the examined chicken Products $(n=25)$.

\begin{tabular}{|c|c|c|c|c|c|c|c|c|}
\hline Product & \multicolumn{2}{|c|}{ Nuggets } & \multicolumn{2}{|c|}{ Luncheon } & \multicolumn{2}{|c|}{ Burger } & \multicolumn{2}{|c|}{ Forter } \\
\hline Isolate & $\mathrm{N}$ & $\%$ & $\mathrm{~N}$ & $\%$ & $\mathrm{~N}$ & $\%$ & $\mathrm{~N}$ & $\%$ \\
\hline \\
\hline \multirow{2}{*}{$\begin{array}{c}\text { Ent. foecales } \\
\text { Ent faecium }\end{array}$} & 1 & 4 & 1 & 4 & 5 & 20 & 10 & 40 \\
\hline & 9 & 36 & 10 & 40 & 10 & 40 & 13 & 52 \\
\hline \multirow{3}{*}{$\begin{array}{l}\text { Staphylococci } \\
\text { Staph aureus } \\
\text { Slaph epidermidis }\end{array}$} & & & & & & & & \\
\hline & 2 & 8 & 3 & 12 & 3 & 12 & 3 & 12 \\
\hline & 5 & 20 & 6 & 24 & 3 & 12 & - & \\
\hline \multicolumn{9}{|l|}{ Mould x yeast } \\
\hline \multirow{5}{*}{$\begin{array}{l}\text { Asp. flavus } \\
\text { Asp. niger } \\
\text { Penicillium } \\
\text { Muocor spp } \\
\text { Yeasts. spp }\end{array}$} & 1 & 4 & - & - & 4 & 16 & 1 & 4 \\
\hline & - & - & 1 & 4 & 2 & 8 & 1 & 4 \\
\hline & 10 & 40 & 9 & 36 & 10 & 40 & 3 & 12 \\
\hline & 3 & 12 & 3 & 12 & 9 & 36 & 2 & 8 \\
\hline & 13 & 52 & 6 & 24 & 19 & 76 & 10 & 40 \\
\hline
\end{tabular}

Table 3: Incidence of identified enteric bacteria isolated from examined chicken Products $(n=25)$.

\begin{tabular}{|l|l|l|l|l|}
\hline Isolat Pro duct & Nuggets & Luncheon & Burger & Frank Forter \\
\hline
\end{tabular}


Assiut Vet. Med. J. Vol. 53 No. 112 January 2007

\begin{tabular}{|c|c|c|c|c|c|c|c|c|}
\hline & $\mathrm{N}$ & $\%$ & $\mathrm{~N}$ & $\%$ & $\mathrm{~N}$ & $\%$ & $\mathrm{~N}$ & $\%$ \\
\hline E Coli & 7 & 32 & 7 & 29 & 8 & 38 & 8 & 32 \\
\hline Klebsiella spp. & 4 & 18.1 & 3 & 12.5 & 4 & 19.0 & 4 & 16 \\
\hline Kl. Ozaene & 1 & & 2 & & 2 & & 2 & \\
\hline Kl. Oxytocia & 3 & & 1 & & 2 & & 2 & \\
\hline Enterobacter spp. & 4 & 18.1 & 6 & 25 & 5 & 23.8 & 5 & 20 \\
\hline Ent agglomerans & 1 & & 5 & & 1 & & 2 & \\
\hline Ent.aerogenes & 2 & & - & & 2 & & 1 & \\
\hline Ent. Cloaca & 1 & & 1 & & 2 & & 2 & \\
\hline Citrobacter spp. & 4 & 18.1 & 6 & 25 & 1 & 4.8 & 4 & 16 \\
\hline Cit. diversus & 3 & & 1 & & 1 & & 2 & \\
\hline Cit. frundii & 1 & & 5 & & - & & 2 & \\
\hline Proteus spp. & 2 & 9.0 & 1 & 4.25 & 1 & 4.8 & 2 & 8 \\
\hline Pr. vulgaris & 1 & & - & & - & & 1 & \\
\hline Pr. merabeli & 1 & & 1 & & 1 & & 1 & \\
\hline Provedensia & - & & - & & 1 & & 1 & 4 \\
\hline Edwardsiella & 1 & 4.5 & 1 & 4.25 & 1 & 4.8 & 1 & 4 \\
\hline Total & 22 & & 24 & 100 & 21 & & 25 & 100 \\
\hline
\end{tabular}

\section{DISCUSSION}

In recent years there is great awareness of food poisoning and how such is of public health hazards. This is due to consumption of food especially meat and its products contaminated with various hazard kinds of microorganisms. Different sources of contaminations, from the chicken carcass itself and throughout the processing plane and their products. The total bacterial count is one of the most accurate and important tests to be taken as an indication of the hygienic measures applied during processing and the most reliable method for detection of sanitary processing of storage of food production (Miskimin et al., 1976).

Table (1) Shows the total mesophilic bacterial count (100\%) of each chicken nuggets, luncheon, burger and frankfurter respectively with mean values of $2.6 \times 10^{5} \pm 8.9 \times 10^{4}, 4.3 \times 10^{4} \pm 5.7 \times 10^{3}, 3.1 \times 10^{5} \pm$ $7 \times 10^{4}$ and $1 \times 10^{5} \pm 3.3 \times 10^{4}$ respectively, nearly similar results were obtained by Refae (1988), Hefnawy and Moustafa (1990), Edris, et al., (1992), Mousa, et al., (2001), Hala et al., (2002) Farag, (2004), Noha and Gehad (2005) but Duishaver and Anatt (1978) had somewhat higher results, The highly aerobic plate count often indicates contamination of raw material or unsanitary measures during processing (ICMSP, 1978). Also it may be due to unsuitable environmental condition during storage.

Total Thermophilic bacterial count: - Table (1) revealed that, in chicken nuggets and luncheon all the examined samples $(100 \%)$ of each were positive with mean values of $1 \times 10^{5} \pm 3.4 \times 10^{4} \mathrm{cfu} / \mathrm{g}$ and $1.1 \times 10^{4}$ $\pm 2.7 \times 10^{3}$ respectively, but in chicken burger and frankfurter samples 
$(92 \%)$ of each with mean values of $8 \times 10^{4} \pm 2.6 \times 10^{4}$ and $3.6 \times 10^{4} \pm$ $1.2 \times 10^{4}$ c.f.u / g.

It was found that, by increasing the temperature to about $65^{\circ} \mathrm{C}$ in vacuum packaged atmosphere resulted in great reduction in the number of aerobic microorganisms \& mould and yeast count (Yuste, et al., 2000, Cegielska and pikul, 2001 and Houf, et al., 2002).

Total psychrophilic bacterial count: - Table (1) showed that, freezing and chilling during manufacture and storage of the poultry products have a major effect on the growth of microorganisms as in chicken nuggets it was $76 \%$ of all examined samples with a mean value of $6.9 \times 10^{4} \pm 2.10 \times 10^{4}$, while in luncheon, burger and frankfurter, $88 \%, 88 \%, 84 \%$ with mean values of $6.2 \times 10^{3} \pm 9 \times 10^{2}, 3.9 \times 10^{4} \pm$ $1.9 \times 10^{4}$ and $1.1 \times 10^{5} \pm 4.6 \times 10^{4}$ respectively. Most of Psychrophilic bacteria are non - pathogenic but their presence in high number may be decrease the keeping quality of the products and makes it unfit for human consumption (Elliott and Michener, 1964) On the other hand Jurgen, (1994) Estimated that the killing temperature of Psychrotrophlic bacteria ranged from $60-70^{\circ} \mathrm{C}$.

Table (1) revealed that Enterococci were highly found in luncheon and frank forter as $64 \%$ of each with mean valui of $135 \pm 34.5$ and $133.7 \pm 37.7$ respesluely while in burger was $48 \%$ with mean value $145.8 \pm 45.5$ and in nuggets $36 \%$ with mean vals $33.3 \pm 5.3 \mathrm{cfu}-1 \mathrm{~g}$.

Table (2) revealed that Entero coccus faecium was detested as 36, 40,40 and 52\% in Nuggets, luncheon Burger and frank- forter respectively, while Entero coccus faecales was found in much less incidences it was $4 \%$ in both nuggets and luncheon, and somewhet increased up to $20 \%$ in Burger the highest was detected in furter as $40 \%$ The presence of Enterococci indicates microbiological proliferation which include all the multiplication of wide range of pathogenic and toxigenic organisms and constituting a public health hazard.

Total staphylococci count :- From Table (1) The highest rate of Staphylococci was found in chicken luncheon $(36 \%)$ with a mean value of $154.4 \pm 39.9$ but in nuggets, burger and frankfurter it were $(28,24$, $12 \%)$ with mean values of $41.4 \pm 12.2,95 \pm 50.3$ and $250 \pm 120.1$ c.f.u./g respectively. Nearly similar results were obtained by Dempster et al., (1973) The identified Staphylococci were Staph. aureus and Staph epidermidis. Their isolation rate in Chicken luncheon appear as a highest one $(12 \%, 24 \%)$ followed by nuggets $(8 \%, 20 \%)$, burger $(12 \%, 12 \%)$ and frankfurter gave only Staph. aureus (12\%. Table (2) Similler results were recorded by Noha and Gehad (2005) Higher rates were recovered, 
by Mousa, et al., (2001) where Staphylococci were detected in $48 \%$, $32 \%$ in Breast and thigh muscles of broilers. Staph. aureus as important in relation to poultry meat hygiene because of its ability to produce enterotoxins. which may cause food poisoning in human. Staphylococcal food poisoning is one of the major causes of food borne illness Jablonski and Bohach (1997). The source of Staph. aureus entrance to the food are variables. Human as animal contamination as well as nasal passage of many persons are dealer with those organisms (Frazer and Westhoff, 1988) Moreover, poultry by it self performs a major source of Staphylococcus Litjens and vanwill'yam, (1989). Moreover Forbes et al., (1998) stated that, the presence of Staph. aureus may be due to contamination of food equipments, the production of Staph.aureus exotoxin, heat stable toxins, causes nausea, vomit ion, retching, abdominal cramp, prostration, diarrhea in human, in more severe cases, headache, muscle cramp and transient changes in blood pressure (Acha and Szyfres 1991 and Gracey et al., 1999). The results agreed with those recorded by (Noha and Gehad (2005) also in accordance with permissible limits as given by E.O.S.Q.C.(1995) and agreed with the findings of Farag (2004) and Essa et al. (2004).

Concerning Coliform count as illustrated in Table (1) revealed incidence of $88,96,84$ and $72 \%$ in nuggets, luncheon, burger and frankfurter respectively with mean value of $2.1 \times 10^{4} \pm 2.1 \times 10^{3}, 2.3 \times 10^{4}$ $\pm 2.2 \times 10^{3}, 3.9 \times 10^{4} \pm 1 \times 10^{4}$ and $6.4 \times 10^{3} \pm 1.3 \times 10^{3}$.respectively.

E. coli was the major member of Coliform 32, 29, 38 and $32 \%$ in nuggets, luncheon. burger and frankfurter. Klebsiella 18.1, 12.5, 19 and 16\%, Enterobacter 18.1, 25, 23.8 and 20\%, Citrobacter 18.1, 254.8 and $16 \%$, Proteus 9, 4, 25, 4.8 and $8 \%$ also Provedencia and Edwardsiella were recovered in lower incidence as illustrated in Table (3) Nearly similar results were recorded by El-Mossalami (1988) Mira (1989) and Essa et al. (2005) The contamination of food by Coliform lead to clinical signs included. diarrhea, abdominal cramps, nausea, vomiting chills, fever within 2-36 hour following ingestion of contaminated food (Varman and Evans, 1991). Klebsiella and some strains of Enterobacter have been found among urinary tract and other pyogenic infections (Mackie and Maccartney 1962). Moreover enteric infection could be caused by Citrobacter species (Chambers, et al., 1976).

Total mould and yeast count:- Table (1) revealed that, chicken burger was the highest contaminated product $(88 \%)$ followed by luncheon $(60 \%)$, nuggets $(52 \%)$ and low percentage was $36 \%$ in forter. the mean values of mould and yeast were $1.4 \times 10^{4} \pm 2.4 \times 10^{2}, 2.7 \times 10^{3} \pm$ 
$1.4 \times 10^{3}, 8.9 \times 10^{3} \pm 3.1 \times 10^{3}$ and $3.9 \times 10^{3} \pm 1 \times 10^{3}$ in nuggets, luncheon, burger, and frank forter respectively simller results were recorded by ElShazely (1976), Ismail et al., (2000).

Yeast and mould can grow at a wide range of temperature, therefore one can find mould at any temperature under which foods are held. The highest numbers in examined poultry products gave an indication about lack of heat processing. This agreed with Frazer and Westhof (1988)

\section{REFERENCES}

Acha, P.N. and Szyfres, B. (1991):" Zoonoses and communicable disease common to man and Animals

Baird Parker, A.C. (1964): An important diagnostic and selective medium for isolation coagulase positive Staph cocci J. Appl. Bact. 25: 12-14

Bullerman, L.B. (1979): Significance of mycotxinsto to food safety and human health .J. Food prot., 42: 565

Cegielsk, Radzicjewska and Pikul (2001): Effect of gas atmospheres storage temperature and time on the quality and Shelf life of sliced poultry sausage Archiv. fur Agefluegelkunde 65 (6) 274280

Chambers, J.V.; Berchbi, D.O. and Hill, D.A. (1976): Microbiological survey of ground beef in chio. J. milk food technol., 39: 530.

Cruckshank, C.; Duguid, J.P.; Marmion, B.D. and Swain, R.H.A. (1975): Medical microbiology 12 Th Ed, Livengiston Robert Setvenson Edenburg,

Doyle, M.P. and padhye. V.V. (1989): Escherchia coli pp. 235 - 281. In M.P. Doyle (ed.). Food borne bacterial pathogens. Marcel; Dekker. Inc. New York and Basel.

Duishaever, C.L. and Anatt, D.R. (1978): Bacteriological evaluation of frankfurters in the Canandian retail markets. J. food prot., 4:770 - 774 .

Edris, A.M.; Abd El-Rahman, M. and Mousa, M.M. (1992): Microbial evaluation of some retailed cut - up chicken and poultry meat products. Benha Vet.Med. J. 3: 154-166.

El-Khateib, T.; Abdel - Rahman, H.; Hamdy, M. and Lotfi, A. (1988): poultry meat products in Egypt; proximal body composition and microbiological quality. Fleischwirtschaft, 68: 756. 
Elliot, R.P. and Michener, H.D. (1994): Microbiological standards and handling cods for chilled and frozen food. A review Adv. food Res., 13:349-396.

El-Mossalami, M.K. (1988): Surface bacteria of slaughter cattle in cattle in modern abattoir. Thesis, M.V. Sc (Meat Hygiene) Fac. Vet. Cairo university.

El-Shazly, M.G. (1976): Chemical and Technological studies on luncheon M.V.Sc.Alexandria Univ.

EOSQC (Egyptian Organization Specification and Quality Control) (1995): Standard specification No. 2910, chilled chicken

Essa, H.H. Makar, N.H. and Sohair, Z.H. (2004): Bacteriological Evaluation of Chicken luncheon in Assuut City Assiut Vet. Med . J. Vol. 50 No 102 64: 71

Farag, M.A. (2004): Quality evaluation of poultry products in Assiut

City. ph. D. Thesis Faculty of Vet. Med. Assiut University.

Forbes, B.A.; Sahm, D.F. and weissfeld, A.S. (1998):" Diagnostic Microbiology ". 10th Ed. Mosby. Inc. 11830 westline.

Frazier, W.C. and Westhoof, D.C. (1988): Food Microbiology. 3 rd Ed., TATA McGraw Hall publ. Comp., Limited New Delhi.

Gracey, L.F.; Collins, D.S. and Huey, R.J. (1999): " Meat Hygiene " $10^{\text {th }}$ Ed. Horcourt Brance and com - pany

Hala, H. Wehab and Goda, A.M. Aideia (2002): Chemical and bacteriological studies on different types of luncheon. Egypt Vet. Med. Assoc., 68 (6): $103-112$.

Hefnawy, and Moustafa, S. (1990): Quality evaluation of ready to eat poultry Assiut Vet. Med. J., 23 ( 46 ) .

Houf, K.D.; Lutter, L.; Van Hoef, J. and Vandamme, P. (2002):

Occurrence and distribution of Areobacter species in poultry processing. Fac. Vet. Med., Belgium, 65(8): 1233-1239.

I.C.M.S.F (international Commission of Microbiological Specification of foods): 1978 Microorganisms Ecology of food. University of Toronto Press. Toronto, Ontario, Canada.

Ismail, S.A.; Deak, T.; El-Rahman, H.A.; Yassin, M.A. and Beuchat, L.R. (2000): Presence and changes in populations of yeasts on raw and processed poultry products stored at refrigerature. University of Georgia, USA, 62 (1-2): 113 - 121.

Jablonski, L.M. and Bohach, G.A. (1997): Staphylococcus aureus, P.353 - 373. In M.P. Doyle, L. R. Beuchat, and Frotiers. American Society for Microbiology: Fundamentals and Frotiers. American Society for Microbiology, Washington, D.C. 
Jurgeen, (1994): Facts to know about heating food staffs Dieflelscherei 9/ 1994

Krieg, N.R. and Holt, J.G. (1984): Berges Manual of Systemic Baceriology Vol.I William and Wilkins company Bltemor London.

Levin, P.; Rose, B.; Green, S.; Ransom, G. and Hill, W. (2001): pathogen tesing of Ready to eat meat \& Poultry products collected at Federally Inspected Establishment in the united states. 1990 to 1999. J. Food Production $64: 1188-1193$.

Litjens, J.B. and williyam, V. (1989): A case of swallen head syndrome in a flock. Of guinea foul Tijdsch Diergeneskd. J. poult., 114 (13) :719- 720 .

Mackie, K.J. and Maccartney, J.E. (1962): Handbook of practical Bacteriology. $10^{\text {th }}$ Ed., E \& s Livingstone Ltd., London.

Mira, E.K. (1989): Hygienic status of beef produced in new Cairo abattoir. Thesis. M .V. Sc. Fac. Vet. Med. Cairo University.

Mercuri, A.J. and Cox, N.A. (1979): Coliform and Enterobacteriaceae isolated from selected food. J. Food prot. 42: 712 -714.

Miskimin, D.; Berkowitz, K.; Sollberg, M.; Riha, W.; France, W. and Buchanan, R. (1976): Relationships between indicator organisms and specific pathogens in potentially hazardous foods. J. food Sci., 41 ( 5 ): 1001 - 1006.

Mossel, D.A.; Bijke, P.G.H. and Ederink, (1978): Streptococcus der lancefied group $\mathrm{D}$ in libensmiteln and Trinkwassor inhre Bedeutung Erfassung and Bekampfuge Archiv fur lebensmitelro Hygiene, 29: 121-160.

Mousa, M.M.; Bkhiet, A.A. and Abdel Tawab, E. (2001): Bacteriological aspects of pre - cooked de - boned poultry meat in Damanhour $2^{\text {nd }}$ Int. Scientific Conference. The role of Veterinary Mansoura University.

Noha, R.M. and Gehad, F.A. (2005): Bacteriological status of some chicken products in Cairo govern orate Egypt. Vet., Med. Ass.65 No 3:295-306

Refae, I.R. (1988): Studies on the microflora of some vacuum packed cooked chicken meat products. Agric. Microbiol., Fac. Agric., Cairo University .

Roberts, T. (1988): Salmonellosis control: Estimated economic costs. J .Poultry Sci. 67: 936 - 943. 
Samaha, I.A.; Ebad, A.S.; Bkheet, A.A. and Zeftawi, H.M. (2003): Microbial Change in Chilled Chicken Carcasses Third Int. Conf. Mansoura 29-30 April: 583-594.

Shewan, J.M. (1971): A progress report. J. Appl. Bact. 34: 299-315.

Todd, E.V.D (1989): Preliminary estimates of costs of food borne diseases in the United States. J. Food prot. 52: $595-601$.

Varman, A.H. and Evans, M.G. (1991): Food borne pathgens. An illustrated text Chapter 13, pp267 England; Walfe Publishing Ltd. ISBN 07234, 1521, 8-11.

Yuste, J.; pla, R.; Capellas, P.E. and Mor Mur, M. (2000): High pressure processing applied to

Yuste, J.; Pla, R.; Capellas, M.; Pance, E. and Mor Mur, N. (2000): High pressure processing applied to cooked sausage bacterial population during chilled storage J. Food prot., 63 (8): 10931099. 